\title{
An Inquisitive Scrutiny of the Second Pillar and its Impacts Envisaged on the Ever-Changing CAP
}

\author{
Benjamin Scott WOLLEY ${ }^{1 \star}$, Jernej TURK ${ }^{2}$ \\ ${ }^{1}$ Norwegian University of Life Sciences (NMBU), Department of International Environment and Development Studies/Noragric, \\ Tivoli Building, Universitetstunet 1, 1430 Ås, Norway \\ ${ }^{2}$ University of Maribor, Faculty of Agriculture and Life Sciences, Pivola 10, 2311 Hoče, Slovenia
}

\begin{abstract}
This article provides an overview of the European Union's Common Agricultural Policy (CAP), focusing on its Second Pillar. It begins with a meticulous analysis of the ongoing alterations of the Second Pillar. It further considers how these changes will impact upon CAP as a whole and while moving forward. At the same time the article thoroughly examines the Second Pillar's implications on balanced rural development in European rural communities. With respect to rural communities, consideration is given to the diversity throughout the EU. The article also succinctly addresses both territorial rural development aspects and sustainable environmental management issues. Ultimately, several mainstream projections of further CAP reforms are discussed while noting some weakness that are inherent within true common policy.
\end{abstract}

Key words: CAP, Second Pillar, balanced rural development

\section{INTRODUCTION}

The European Union's Common Agricultural Policy (hence force referred to as EU and CAP respectively) is an ambitious program intended to support and enhance a number of sectors within the field of agriculture and wider. Increasing food production, even at the risk of high costs and externalities, was the cornerstone of the program in its infancy (Gabellieri, 2014). The policy itself has roots stemming from the post-World War II period, as outlined in the Treaty of Rome (Fennell, 1997). The latter being the basis for the EU, which, perhaps, is one of the most iconic attempts at crossnational unity existing in the present world. While there is no denying that the EU is not a perfect system, it has achieved great strides in creating a cohesive unit at a level greater than national. CAP, too, seeks to remove borders from policy, aims to achieve certain standards and targets across members states in the EU with respect to agriculture.
Agriculture is the combination of two activities central to modern and ancient society. The prefix agri- meaning of the land, and culture, more open to interpretation, can perhaps be most succinctly summed as up as the ways of life. Of course, to combine these implies a connection of both people to the land and to one another. Jules Pretty reaffirms this saying, that for as long as natural resources have been under human control, so too have we performed collective action (Pretty, 2002). With this in mind, it is easy to see why a body such as the EU would benefit from a shared policy that shapes such a crucial aspect of life, across any society or background. While a plate of 'local' or 'traditional' food can vary greatly across EU members states, they all require knowledge, inputs, land, labor and capital to arrive at the dinner table. Furthermore, while essential to life, the negative externalities agriculture cannot be dismissed especially with the ever looming threat of climate change (Gómez-Baggethun \& Naredo, 2015). All too often, consumers do not realize or consider these costs, 
especially in the scope of rural communities which produce a great deal of food that is consumed. While the bulk of responsibility for climate change pressures does not fall upon farmers, suggestions often get pressed upon farmers, including rural ones, to make their farms 'green'. CAP's Second Pillar, which explicitly focuses on rural areas includes provisions to ensure sustainable management of the smallscale farms across its territories. While this will be expanded upon in greater detail further below it is important whenever evaluating impacts of policy to see who bears the burden of change. Who benefits and who loses?

The aim of this paper will be to critically examine CAP's Second Pillar, with detail on its impact upon CAP as a whole. Following the introduction, there will be a brief discussion of CAP, a short overview of its functions and its goals. Next expansion upon the Second Pillar will further develop working knowledge of the topic. This will be followed by discussion of how the Second Pillar has impacts upon CAP. A conclusion will follow to bring together the main points of this paper.

\section{The basic financial features of the Common Agricultural Policy (CAP)}

As stated above, CAP had its inception in the postwar period, being initiated formally in 1962. Follow years of violent struggles there was a clear incentive to ensure the peasantry, in this case the farmers, were compensated to level where they would not disrupt unity aspirations (Grant, 1997). Thus, direct farmer payments have been and continue to make up the bulk of CAP's budget. CAP's percentage of the EU budget has dropped greatly from its early days as shown below in Figure 1. In 2017 it was reported that it 37\% of the budget was allocated to CAP, far down from its height of $73 \%$ in 1985 (Parliament, 2017). These reflect the changes in investment over the years which now include sizable increases in infrastructure, security and administration to compensate for the decline in CAP funding.

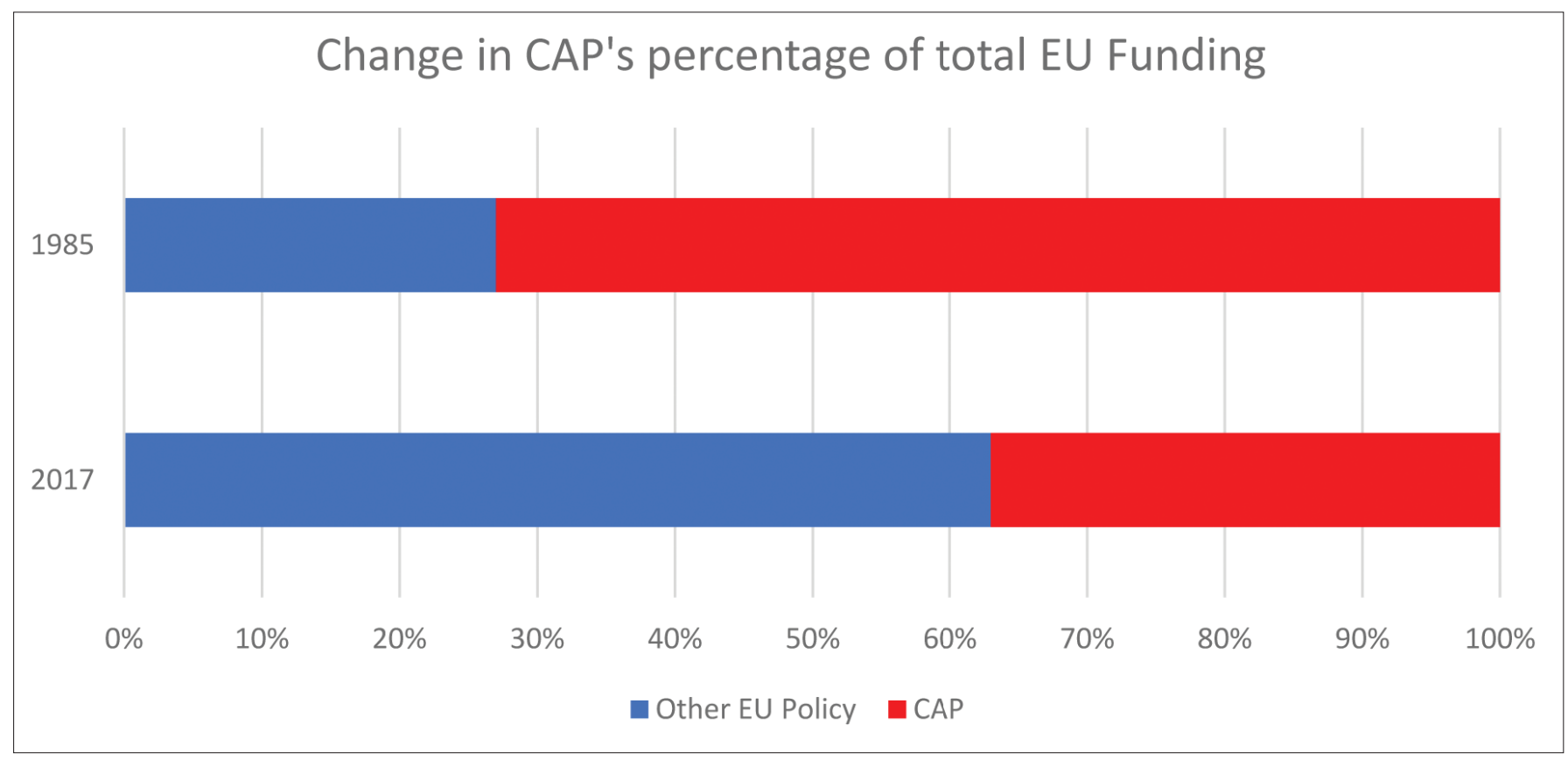

Figure 1: The above graph shows CAP's funding decline as a percentage of total EU budget from 1985 to 2017 , as presented by the Irish Parliament. CAP's funding, represented in red reached a height of $73 \%$ of the total budget in 1985 , declining to a modest $37 \%$ in recent years as fund went to other EU initiatives outside agriculture (Parliament, 2017)

CAP funding supports a variety of services within European agriculture. While these have developed since its inception, CAPs current primary three focus areas for investment are: economically feasible food production, sustainable management of farming practices and rural development (European Comission, 2013). But the funding for threes three is not uniformly distributed. According to the above 2017 report, across the EU 71\% of CAP's budget is allocated to direct payments to farms (i.e. ensuring viability), $5 \%$ to market measures and the remaining 24\% to rural development (Parliament, 2017). The below figure demonstrates the imbalance given to the First Pillar (combined with the small funding of market measures) as well as the small decline in funding year on year:

As the focus of this paper deals with the Second Pillar, and it's support of rural development there will not be great focus on the other aspects of CAP. However, it is important to note that while they will not feature here, there is a healthy amount of debate surrounding other areas of CAP. Some problems identified include CAP's effect on raising food prices, which states receive funds (who benefits and who loses?), environmental concerns relating to agriculture and the possibility of hindering development, instead focusing on solely boosting farmers' incomes (Grant, 1997). While CAP's policies and aims are under constant change, much as environmental, economic and socio-cultural trends change 


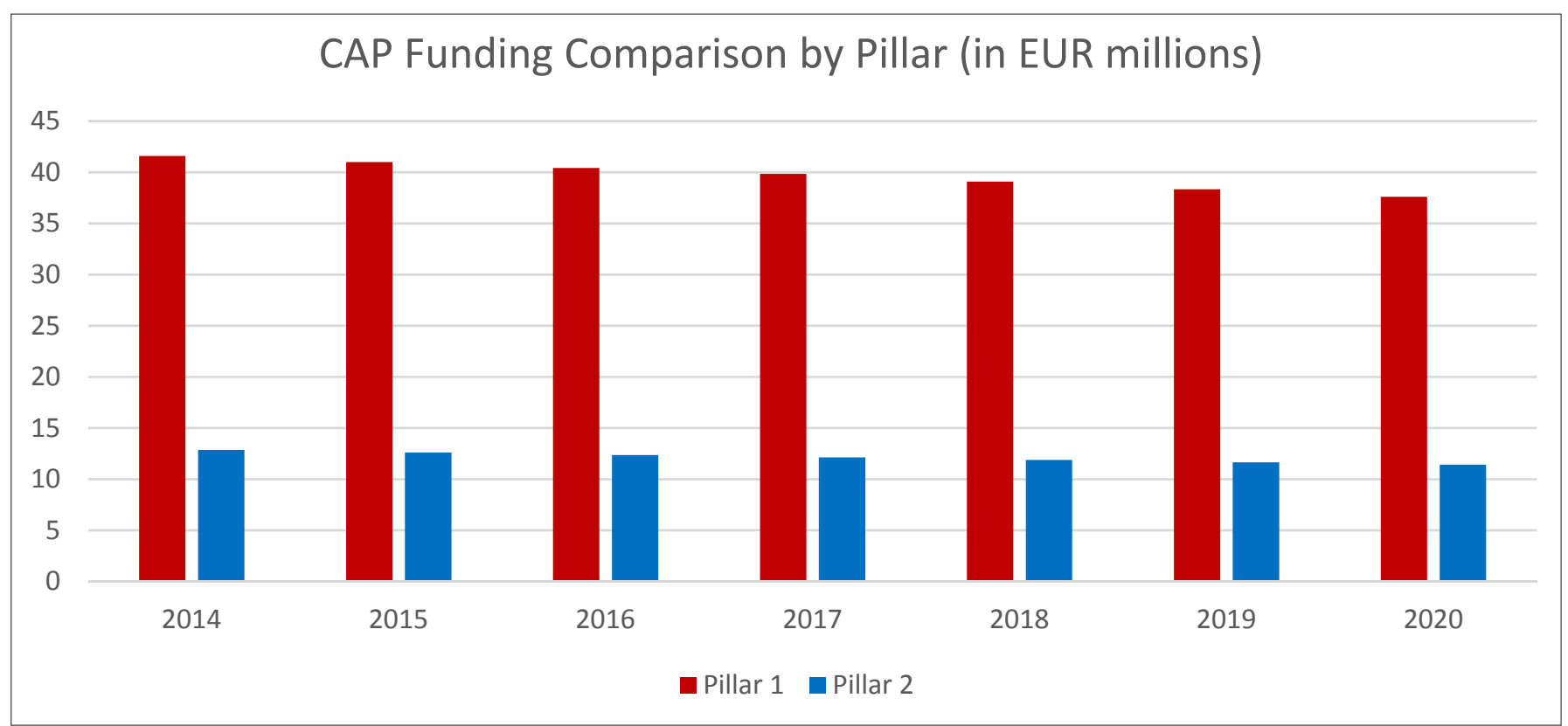

FIGURE 2: The above information was gathered from a European Parliament Fact sheet on CAP spending per pillar between 2014 and 2020. Together CAP averaged 37.8\% of total EU Budget, with the First Pillar (including market measures averaging $1.7 \%$ ) averaging $28.9 \%$ and the Second Pillar averaging $8.8 \%$ of the total budget (Massot, 2019)

in tandem, there is widespread debate on the effectiveness of the program. Looking forward CAP introduced two pillars in an effort to mitigate some of the debate and renew the visions for agriculture in the EU. The first of these pillars focuses on direct payments, which take the majority of CAP funds, and will not be the focus of this paper. Instead rural development will be reviewed with elaboration on the Second Pillar.

\section{The main distinctions of the Second Pillar}

Rural Development, one of CAP's primary aims, has been noted by the EU as a pivotal focus point. The pillar's goal is to support rural areas across the EU while simultaneously meeting social, economic and environmental challenges (Negre, 2019). One important distinction between CAP's two pillars it that while the first is fully funded by the EU, the second is partially funded by the EU and supplemented with regional and national funding (Negre, 2019). This gap is funding mirrors the overall total funds allocated by cap, with around three times as much going to direct payments than to rural development. It should be noted that CAP does have a large budget of 365 billion euros so even the modest percentage it is not a small amount of investment (Rosario \& Robin, 2018). While the investment into the Second Pillar can be considered substantial, there are both positives and drawbacks to the gap in funding from the EU.

Before considering the negatives, it must be noted that assigning partial responsibility for funding to national and local actors can help with cultivation of a sense of ownership and motivation to see the project there. There are numerous examples of community based adaptation being successful when those in the community were give partial or greater levels of ownership and responsibility (Ebi \& Semenza, 2008). This could benefit local and national projects but getting actors involved and creating a more efficient feedback cycle which allows project's status to be communicated among the various levels. On the other hand, EU countries which contribute the least, and hence have lower GDP's and funds which can be allocated will suffer under this model. It cannot be realistically assumed EU members states such as Romania can as easily fill the gap in funds for Pillar II projects as states such as Germany or France. Under this funding model, states which are more successful economically can be expected to benefit greater as they will find less difficulty in project funding and fulfilling goals of the Second Pillar.

To capture the idea and goals of the Second Pillar first the purpose and priorities (according to the European Commission) will be discussed. The European Commission first suggested the Second Pillar in the context of Agenda 2000, an effort to reform CAP and update it to challenges of the time such as an expanding union (European Comission, 1997). The Rural Development Regulation (RDR), was conceived by the EU as a new approach for rural and agricultural development (Dwyer, Ward, Lowe, \& Baldock, 2007). In the year 2000, Rural Development Regulation was established as a 'new' Second Pillar seeking to promote rural sustainable development (Dwyer et al., 2007). Since then it has been implemented in CAP and developed along with the program. Three main goals are listed: fostering agricultural competition, sustainable management in rural areas, and balanced rural development including creating and maintaining employment (Negre, 2019). These three goals are then expanded by six of the following priorities, as outlined by the European Commission:

1. Fostering knowledge transfer in agriculture, forestry and rural areas;

2. Enhancing the competitiveness of all types of agriculture and enhancing farm viability; 
3. Promoting food chain organisation and risk management in agriculture;

4. Restoring, preserving and enhancing ecosystems dependent on agriculture and forestry;

5. Promoting resource efficiency and supporting the shift toward a low-carbon and climate-resilient economy in the agriculture, food and forestry sectors;

6. Promoting social inclusion, poverty reduction and economic development in rural areas (Negre, 2019).

With this outline it is clear that CAP has developed from its earlier days when an increase in food production was considered to be a paramount objective. Indeed currently, at least on paper, it would seem that with the Second Pillar CAP has now become inclusive of present-day problems with respect to the environment, society and economy. The three initial goals offer relatively ambiguous targets, and while the subsequent list of priorities does offer some additional info - on the whole the aims and priorities remain somewhat vague.

In order to really comprehend what functions the Second Pillar performs, it is prudent to look beyond EU briefings that present a simple outline as above, without concrete examples of what can done to achieve these goals. It is important to understand how the EU is operationalizing rural development, as too often development is a blanket term which is repeated and loses its significance. Unfortunately, across multiple EU briefings, fact sheets and press releases about CAP and the Second Pillar, rural development is not defined in a certain manner. Given the great challenges facing rural communities, vague notions are not enough. The briefing regarding the pillar posted by the European Commission does then elaborate further a lengthy "European Menu" of measures which must be included by member states including: restoring agricultural production potential, enhancement of rural services and infrastructure, subsidies for organic farming and payments for ecosystems services, among many others (Negre, 2019). These examples help give life to where the policy of the Second Pillar is aiming to impact.

One of the benefits to revisions of the Second Pillar from previous iterations was its regrouping of measures which were scattered into one cohesive unit (Garzon, 2006). As the Second Pillar has decades in the making, even longer in the case of CAP, developments over time had spread out the measures making it difficult for them to be implemented and monitored, decreasing the chance for a successful outcome. In addition to consolidating formerly scattered practices, there is also a noticeable shift in the Second Pillar from large blueprint models to more territorially focused initiatives (Dwyer et al., 2007). This decentralization marks a noted change from CAP's original model of true common policy and puts more power into national and subnational decision makers. Even further there is a move away from commodity support and market stabilization tools, in favor of longer term projects to improve the working and overall lives of farmers and rural communities (Dwyer et al., 2007). While these aims and methods are not necessarily new within
CAP what offsets them in the Second Pillar toolkit is their consolidation and recognition that to achieve a 'sustainable rural development' individual situations must be assessed. these conditions can differ greatly across EU members states and thus so can the solutions differ in tandem.

One final aspect of the Second Pillar which must be mentioned, is the way in which challenges for rural Europe must be addressed. Across many fields of environmental sciences, there is a call for not just change and adaptation, but transformational change and adaptation. What transformational change refers to is abandoning solutions which respond to issues, instead aiming to address root causes or drivers of said issues (Kates, Travis, \& Wilbanks, 2012). In the face of climate change, incremental responses which offer temporary respite while still allowing the driving cause to continue are not sustainable. Considering some of the problems that rural Europe faces, to include: varying rainfall cycles bringing flooding/drought, growing populations mostly in the south, and significant growth in other parts of the world greatly increasing demand for products; there is a need to respond not only with ecologically sustainable solutions, but also in a socially and economically responsible way.

\section{Theimpact of the Second Pillar on the ongoing CAP reforms}

As noted above the three main goals of CAP's Second Pillar are fostering agricultural competition, sustainable management in rural areas, and balanced rural development including creating and maintaining employment. Each of these will be discussed below regarding how the Second Pillar is impacting these areas of CAP.

EU's 2020 Vision explicitly states that Europe must become more competitive (Dwyer, 2013). It's no secret that other geographic areas of the world can produce goods and food at a much cheaper cost, due to cheaper land, inputs and labor, which often times can mean higher prices for locally produced than for imported food. This is often the case when considering rural and small-scale farmers as their limited production often leaves little chance to develop an economy of scale which can decrease their costs per unit - meaning they must charge more for their products than what a large-scale commercial farm could achieve. When considering transformational change that is promoted by the Second Pillar, a simple subsidy for farmers would be only a temporary solution and not achieve a real difference in the long run, other than supporting the rural farmers income.

Instead the Second Pillar calls for innovation, which requires both skills and information - as noted in the pillar's six priorities above. Keeping in line with the Second Pillar's territorial focus, it is prudent that local actors work both together and with key policy makers to foster knowledge exchange which can lead to innovation (Dwyer, 2013). Forcing innovation is counterproductive, however policy can be used to create conditions which inspire innovation. Instead the innovation of the multifunctional role of agricultural is supported by Pillar II (Râmniceanu \& Ackrill, 2007). One way in which rural farmers have adapted in recent decades 
would be the rise in rural tourism. Despite numbers of farmers dropping by almost half in the past two decades (in the $\mathrm{EU})$, the number of rural tourism sites has grown greatly proving that both transformation change and innovation are applicable in a rural setting (Agostini, 2007). Funding for agri-tourism development in rural areas has helped to increase rural development as has supplemented local income even as agricultural income has declined (Dwyer et al., 2007). Tourism is now a key industry in many rural farming communities across the $\mathrm{EU}$, but there are further ways to increase competitiveness.

Another Second Pillar aspect which is serving to increase competition is simply to increase consumer awareness, which can add value to locally and sustainable produced agri-products (Dwyer, 2013; Dwyer et al., 2007). While consumers normally have a great deal of choice at the supermarket and beyond, it is often that the most considered aspect is the price. However, along modern attitudes towards the environment, there are many consumers who both consider and pay a premium for a product which causes less ecological harm. Across the EU there have been a number of initiatives promoting organic food, local wine harvests and quality regional products, which while more expensive have a much a smaller footprint that imported goods, and often times a higher quality (Dwyer, 2013; Dwyer et al., 2007) . These two methods have been aided with the Second Pillar, but it should also be noted again that since these have a more regional focus the benefits and costs are not uniformly distributed across the EU.

Regarding sustainable management in rural areas the Second Pillar has also had an impact upon CAP. With the plethora of information available regarding climate change and climate stresses brought along with it, it is imperative that agriculture be made as efficient and sustainable as possible. Gravnik et al. perhaps best sum the need for reconstruction and reintegration of agriculture. Reconstruction or better aligning agriculture so that is address not only our needs but also our values, and recognition of its (agriculture) potential to protect the natural environmental as opposed to harm it (Granvik, Lindberg, Stigzelius, Fahlbeck, \& Surry, 2012). And reintegration of agriculture, and its activities and local actors into a diversified rural economy, which recognizes the possibility to bring together the three dimensions of sustainable development: economic, social and environmental (Granvik et al., 2012). At the rural level the Second Pillar gives a number of ways to achieve this.

While the Second Pillar has a very obvious policy focus, it is important to note that any form of development and progress, including rural, is not solely driven by policy. In truth norms, institutions, power structures and resources - along with policy - come together and influence development, and most often not uniformly (Granvik et al., 2012). Karen O'Brien suggests a nested sphere model, where the center, the practical sphere, is the easiest to implement but offers the least in terms of grand transformation (O’Brien \& Sygna, 2013). The middle sphere, political, has more weight with respect to change but with harder implementation, and the outer personal sphere is the hardest to enact, involving changing individual views, but can achieve the greatest level of transformation (O'Brien \& Sygna, 2013). Of course, a combination of the three is more common than a single reliance, and Cap's Second Pillar is an example of this. Rural development policy can be seen as political, but it often incorporates practical solutions and leaves room for personal change (such as choosing local over imported produce). These three spheres working together can be harnessed for rural sustainable management.

One way in which Pillar II helps promote sustainable rural management is through its recognition of ecosystems services. Denmark, for example, has introduced a voluntary scheme where farmers can maintain regulating ecosystems services (erosion control, flooding control, pollination, etc.) and be paid through local based contracts with nearby cities (Kristin Magnussen, 2014). While this brings about debates regarding valuation and commodification of nature, it is a prime example of how rural resources can be managed. Across several Nordic states there exist payment for ecosystem services (PES) schemes, which have been co-financed by Pillar II funds (Kristin Magnussen, 2014). These payments can direct aid rural development by diversifying payment of farmers/landowners and at the same time protecting services which the environment provide. With respect to Gravnik et al., this is an example of reintegration of agriculture and multiple dimensions of sustainable rural development.

The final main goal of CAP's Second Pillar is balanced rural development. It has already been noted that with the Second Pillar there is a shift from commodity support to policy which focuses on territorial rural development and sustainable environmental management (Lowe, 2002). This promotion of decentralized decision making helps to aid in a more balanced development process, as local needs and goals can be considered instead of a 'one size fits all' top down approach. This method has helped in a number of ways to create a more balanced development which can benefit diversification of rural agricultural activities, land improvement, enhanced marketing (informing consumers), and landscape conservation - to name only but a few (Lowe, 2002). It should also be noted that the above example are only some of the many methods that can be use to achieve Pillar II's goals. They should be assessed locally to see which would be most beneficial. By moving to a less blueprint, and more specialized approach for certain areas Pillar II has allowed for greater balance, but at the same time this approach is moving away from initial plans for CAP.

A true common policy is applicable across all covered areas, Pillar II however breaks this trend by allowing specific areas to focus on specific solutions. The original intent of CAP, to increase food production, may not be what a farm in rural Slovenia needs to do most now when instead it could focus on creating awareness for its craft products or promoting itself as an agritourism destination. In the financial perspective 2021-2027 the principle of subsidiarity allows each member state to design its genuine and independent policy measures implementation framework. Slovenia would likely seek to gain ground first and foremost in the domain of sustainable agriculture by further promoting young farmers scheme, encouraging knowledge transfer and innovation, stimulating digitalization in agriculture, strengthening environmental awareness and ultimately making all the endeavour for an effective and balanced rural development. With the flexibility introduced by Pillar II this has become more possible, as well 
when considering that rural development projects are not solely funded by CAP but also at a national and subnational (cohesion policy/funds) level.

\section{CONCLUSIONS}

As a whole the impacts of the Second Pillar on CAP may not seem novel, especially when the pillar essentially repackaged former goals and methods into a new consolidated toolkit for rural development. However, this has allowed a greater deal of focus in rural areas as it no longer is constrained by CAP's blueprint goals for the entire territory. Member states must make up for gaps in CAP funding for rural development which will provide to be a challenge for less wealthy countries. However, this also allows them to diversify methods for farmer and rural community income and foster conditions for innovation and transformational change (Râmniceanu \& Ackrill, 2007). While Pillar II's funding requires greater fundraising when compared to Pillar I, this may not be viewed as a negative for everyone. The fact that funding must come from members states fosters a sense of ownership for projects, which could make support for efforts stemming from Pillar II better received and adhered to. As so much of our future concerns lie with climate change, this diversity in tackling rural challenges allows Europe to simultaneously address the three spheres of transformational adaptation and make the best use and management of resources. Together these offer a greater chance to mitigate the effects and address the drivers of climate change itself.

While rural Europe faces and will continue to face challenges for the years to come, Pillar II offers support to the rural communities who often do their work unseen by many inside the 'big city' bubble who are too far detached from the agricultural processes taking place. Schemes like as payments for ecosystems services, such as those funded by Pillar II, can help reintegrate agricultural awareness into daily lives on those who depend on it but do not recognize it. Additionally, Pillar II's departure from commodity subsidies has brought things such as increasing consumer awareness and diversity of rural income methods (such as tourism) as a key feature to the policy. These have helped increase rural income and are more sustainable in the long term than direct payments. Individual assessments across Pillar II projects in EU territory are difficult considering the size and scope. However, CAP as a whole could benefit from greater feedback of both successes and failures of the more decentralized approach of Pillar II and its impacts for rural communities.

Lastly, it must be noted that while improvements in rural communities and agriculture are of great importance, there is further need to apply the same treatment to large-scale commercial farming. Given the level of support provided by both Pillars I and II, small scale farming in Europe is a difficult business with many challenges. It is easy to forget with such focus on this sector, that there is also great reliance on large operations which often employ a small workforce in proportion to output and have a much greater impact on the environment. Sustainable management in rural communities is not enough to declare them as winners as they are depending on how markets act as a whole and the effects reverberate even stronger in vulnerable locations the fiercest.

\section{REFERENCES}

1. Agostini, S. (2007). Learning sustainability of rural tourism: farm competitiveness and landscape health risk assessment. Agricultural Engineering International: CIGR Journal.

2. Dwyer, J. (2013). Transformation for sustainable agriculture: what role for the second Pillar of CAP? Bio-based and Applied Economics Journal, 02(1), 2947. Retrieved from http://ageconsearch.umn.edu/ record/149218/files/12174-23938-1-PB.pdf doi:ISSN 2280-6180 (print)

3. Dwyer, J., Ward, N., Lowe, P., \& Baldock, D. (2007). European Rural Development under the Common Agricultural Policy's 'Second Pillar': Institutional Conservatism and Innovation. Regional Studies, 41(7), 873-888. doi:10.1080/00343400601142795

4. Ebi, K. L., \& Semenza, J. C. (2008). Community-Based Adaptation to the Health Impacts of Climate Change. American Journal of Preventive Medicine, 35(5), 501-507. doi: https://doi.org/10.1016/j.amepre.2008.08.018

5. European Commision. (1997). Agenda 200: For a stronger and wider union. Retrieved from Luxembourg: https:// web.archive.org/web/20060912121522/http://aei.pitt. edu/3137/01/000033.PDF

6. European Commision. (2013). The common agricultural policy (CAP) and agriculture in Europe - Frequently asked questions [Press release]. Retrieved from https:// ec.europa.eu/commission/presscorner/detail/en/ MEMO_13_631

7. Fennell, R. (1997). The Common Agricultural Policy: Continuity and Change: Clarendon Press.

8. Gabellieri, N. (2014). The Set Aside Programme as selfcriticism of the CAP; the Province of Pisa case study. Scienze del Territorio, 2, 195-214.

9. Gómez-Baggethun, E., \& Naredo, J. M. (2015). In search of lost time: the rise and fall of limits to growth in international sustainability policy. Sustainability Science, 10(3), 385-395.

10. Grant, W. (1997). The Common Agricutlural Policy. Hampshire: MacMillan Press Ltd.

11. Granvik, M., Lindberg, G., Stigzelius, K.-A., Fahlbeck, E., \& Surry, Y. (2012). Prospects of multifunctional agriculture as a facilitator of sustainable rural development: Swedish experience of Pillar 2 of the Common Agricultural Policy (CAP). Norsk Geografisk Tidsskrift - Norwegian Journal of Geography, 66(3), 155166. doi:10.1080/00291951.2012.681684

12. Kates, R. W., Travis, W. R., \& Wilbanks, T. J. (2012). Transformational adaptation when incremental adaptations to climate change are insufficient. Proceedings of the National Academy of Sciences, 109(19), 7156. doi:10.1073/pnas.1115521109

13. Kristin Magnussen, B. H., Marianne Zandersen. (2014). Ecosystem Services: In Nordic Freshwater Management. Copenhagen: TemaNord.

14. Lowe, P., Buller, H., \& Ward, N. (2002). Setting the 
next agenda? British and French approaches to the second pillar of the Common Agricultural Policy. Journal of Rural Studies, 18(1), 1-17. doi:10.1016/s07430167(01)00025-0

15. Massot, A. (2019). The Common Agricultural Policy in figures. Fact Sheet. European Parliament. Brussels.

16. Negre, F. (2019). Second pillar of the CAP: rural development policy. Retrieved from: https://www. europarl.europa.eu/factsheets/en/sheet/110/secondpillar-of-the-cap-rural-development-policy

17. O’Brien, K., \& Sygna, L. (2013). Responding to climate change: the three spheres of transformation. Proceedings of transformation in a changing climate, 16, 23.

18. Parliamentary Budget Office (PBO) of the Houses of the Oireachtas (Irish Parliament). (2017). An Overview of the Common Agricultural Policy (CAP) in Ireland and potential regional and sectoral implications of future reforms. Dublin Retrieved from https://data.oireachtas. ie/ie/oireachtas/parliamentaryBudgetOffice/2018/20 18-08-17_an-overview-of-the-common-agriculturalpolicy-cap-in-ireland-and-potential-regional-andsectoral-implications-of-future-reforms_en.pdf.

19. Pretty, J. (2002). Agri-Culture: Earthscan Publications Ltd.

20. Râmniceanu, I., \& Ackrill, R. (2007). EU rural development policy in the new member states: Promoting multifunctionality? Journal of Rural Studies, 23(4), 416429. doi: https://doi.org/10.1016/j.jrurstud.2006.10.003

21. Rosario, D., \& Robin, C. (2018). EU budget: the Common Agricultural Policy beyond 2020 [Press release] 


\section{Analitična študija drugega stebra in presek učinkov njegovega delovanja na nenehno spreminjajočo se SKP}

\section{IZVLEČEK}

Pričujoči članek analizira Skupno kmetijsko politiko (SKP) Evropske unije s posebnim poudarkom danim obravnavi njenega 2.stebra. V uvodnem delu študije so podrobneje raziskani elementi nenehno se spreminjajočega drugega stebra SKP. Izdelana študija zelo natančno secira spremembe znotraj drugega stebra SKP in proučuje vpliv le-teh na uravnotežen razvoj podeželja v evropskih ruralnih območjih. V tem kontekstu je bila na ravni celotne EU ugotovljena določena stopnja raznolikosti. Pri tem članek naslavlja tako vidik teritorialnega razvoja podeželja, kot na drugi strani obravnava upravljanje z okoljskimi dejavniki skladnega razvoja. V sklepnem delu raziskave so predstavljene različne projekcije nadaljnjih reform SKP.

Ključne besede: SKP, drugi steber, uravnotežen razvoj podeželja 